\title{
A Comparison of Germination and Early Growth of Four Early Successional Tree Species of the Southeastern United States in Different Soil and Water Regimes
}

\author{
JAMES E. MOORE ${ }^{1}$ AND ELIZABETH P. LACEY \\ Department of Biology, The University of North Carolina at Greensboro, Greensboro 27402
}

\begin{abstract}
To learn more about the basic biology of exotic relative to native tree species we conducted a greenhouse experiment comparing the germination and early seedling growth of four early successional tree species found in the southeastern United States: two exotics (Ailanthus altissima and Paulownia tomentosa) and two natives (Liquidambar styraciflua and Platanus occidentalis). Five soil types and three water regimes were used for the experiment. Liquidambar and Platanus, the native species, germinated significantly more quickly and were more sensitive to soil type than were the exotics, Ailanthus and Paulownia. Platanus grew tallest, and along with Paulownia, accumulated the greatest total biomass. Ailanthus alone exhibited a high root/shoot ratio in all soil types. In addition, species differed in their response to soil types for multiple growth traits. The results suggest that native tree species could be used to help retard the establishment of invasive tree species on bare soil.
\end{abstract}

\section{INTRODUCTION}

Because invasive exotics are often extremely difficult and expensive to control, it is important to identify efficient strategies for limiting their spread (Byers et al., 2002; Buckley et al., 2004). Studies have suggested that competition or predation from native species may slow invasive species (Newsome and Nobel, 1986; Simmons, 2005; Mandryk and Wein, 2006), which suggests that management programs might effectively use natives to control invasives. The value of this strategy, however, will depend on the basic biology of each species being used, e.g., conditions that favor the establishment of the invasive relative to the native, interactions between the invasive and exotic.

Because we have found only one study that compares the germination and early establishment of invasive and exotic trees that overlap in range (Butterfield et al., 2004), we conducted an experiment that compared the germination and early seedling growth of four tree species found in the southeastern United States: two native early successional tree species, Liquidambar styraciflua L. and Platanus occidentalis L., and two exotic species, Ailanthus altissima (Mill.) Swingle and Paulownia tomentosa (Thumb.) Sieb. \& Zeec. Ex Steud. Hereafter, we refer to the species by the genus only. Ailanthus is a USDA Forest Service "category 1" invasive (Owen, 2002), meaning it poses significant threats to natural ecosystems and commercial forestry practices (Miller, 1998). Paulownia has not yet been categorized, however, it is becoming a more prominent member of the local flora. Both exotics frequently establish on bare soil in disturbed areas, such as on construction sites, railroad rights of way and roadsides. We compared the germination and seedling growth of the four species on five soil types and under three water treatments. The goals were to determine: (1) if germination and early growth differed between these four species and (2) if soil type and water regime affected germination and growth. Two other species were initially included in the study, Albizia julibrissin Durraz., an exotic and Liriodendron tulipifera L., a native, but were subsequently dropped from the experiment due to poor germination.

\footnotetext{
'Corresponding author present address: Department of Biology, The University of Memphis, Memphis, Tennessee 38152; e-mail: jmoore9@memphis.edu
} 
TABLE 1.-Mean $\mathrm{pH}$ and soil macronutrient levels for each soil type representing two distinct regions of North Carolina. Bold letters indicate piedmont soils ( PD $_{\mathbf{S}}$, Piedmont Disturbed no organic matter; $\mathbf{P D}_{\mathbf{U}}$, Piedmont Disturbed + organic matter; PF, Piedmont forested); while italics indicate coastal plain soils ( $C D$, Coastal Plain disturbed; $C F$, Coastal Plain forested). Nutrient analyses performed by the North Carolina Department of Agriculture (4 samples per soil)

\begin{tabular}{lcccccr}
\hline \hline & $\mathrm{pH}$ & $\mathrm{P} *$ & $\mathrm{~K} *$ & $\mathrm{Ca} \%$ & $\mathrm{Mg} \%$ & $\mathrm{Mn}^{*}$ \\
\hline$C D$ & 4.9 & 164.5 & 39.8 & 31.8 & 13.0 & 41.8 \\
PD $_{\mathbf{S}}$ & 5.4 & 0 & 43.3 & 61.3 & 19.3 & 139.8 \\
PD $_{\mathbf{U}}$ & 5.2 & 4.25 & 30.0 & 46.3 & 18.5 & 1224.3 \\
PF & 4.8 & 3.5 & 45.8 & 29.0 & 15.5 & 261.5 \\
$C F$ & 4.7 & 17.8 & 54.0 & 24.8 & 15.0 & 24.5 \\
\hline
\end{tabular}

*'s indicate P, K, and Mn macronutrient index levels based on protocol from Mehlich, 1953

$\%$ 's show percent of macronutrient as \% of the Cation Exchange Capacity (CEC)

\section{METHODS}

Seed and soil collections.-Seeds of Ailanthus, Paulownia and Platanus were collected from three - many trees along roadsides in North Carolina in fall 2004. Liquidambar seeds were collected from two North Carolina Forest Service stands. All seeds were cold/dry stratified at $12 \mathrm{C}$ for $8 \mathrm{mo}$ as suggested by Bonner (1974 a, b), Bonner and Burton (1974), and Little (1974). For each species, seeds from all sources were mixed before sowing.

Samples of five soil types were collected from the piedmont and coastal plain regions of North Carolina. The sandy loam coastal plain forested (CF) and clayey piedmont forested (PF) soils were collected from undisturbed $(>50 \mathrm{y}$ old) forests. Both soils had well developed $\mathrm{O}$ and $\mathrm{A}$ horizons. One of the piedmont disturbed $\left(\mathrm{PD}_{U}\right)$ soils, a silty loam, came from a previously forested site that had been cleared for a small housing development less than 3 mo before we sampled it. The soil was oxidized and brown in color and resembled the two forest soils in that it contained organic matter from $\mathrm{O}$ and $\mathrm{A}$ horizons. However, it differed from the forest soils because the organic matter had been mixed with the $\mathrm{B}$ horizon in the process of clearing. The other piedmont disturbed $\left(\mathrm{PD}_{\mathrm{S}}\right)$ soil, a clay loam collected beside a newly constructed parking lot, was oxidized and orange in color. Organic matter from the upper soil layers was missing. The sandy loam coastal plain disturbed (CD) soil was collected from a sandy agriculture field used to produce a cover crop. The field had not been tilled for $15 \mathrm{y}$ and lacked organic matter. The Georgeville and Mecklenburg soils (PF, $\mathrm{PD}_{\mathrm{U}}$ and $\mathrm{PD}_{\mathrm{S}}$ ) are found from Virginia to Georgia, while the Marvyn soils (CF, CD) are found in North Carolina and Alabama respectively (NRCS, 2008 Soil Extent Mapping Tool $(\mathrm{SEM}))$. The coastal plain soils had the lowest water-retention capacity, based on wet weightdry weight soil measurements (wet weight - dry weight: $\mathrm{CD}=549.5 \mathrm{~g}$; $\mathrm{PD}_{\mathrm{S}}=652.4 \mathrm{~g} ; \mathrm{PD}_{\mathrm{U}}$ $=578.1 \mathrm{~g} ; \mathrm{PF}=670.1 \mathrm{~g} ; \mathrm{CF}=510.1 \mathrm{~g}$ ). Nutrient analyses showed large differences in $\mathrm{P}$ and Mn but not in the other macronutrients tested (Table 1). The ribbon method was used for determining soil texture.

Experimental design.-We used a split plot design to examine the effects of soil type and soil water availability on germination and early seedling growth. Within each of two blocks were three water treatments. Within each water treatment per block, there were two randomly placed pots per soil type per species. Thus, the experiment included a total of 240 pots (2 blocks $\times 3$ water treatments $\times 4$ species $\times 5$ soil types $\times 2$ replicate pots/species/soil type/ water treatment/block). In Jun. 2005, we placed on top of the soil in each pot 10 seeds to mimic natural dispersal. Thirty-percent shade cloth covered the greenhouse to prevent 
TABLE 2.-Mixed-model results for germination and growth response variables. Statistically significant F-values indicated by asterisks: ${ }^{*}=\mathrm{P}<0.05,{ }^{* * *}=\mathrm{P}<0.001$. Abbreviations: $\mathrm{spp}=$ Species

\begin{tabular}{|c|c|c|c|c|c|}
\hline & $\begin{array}{c}\text { Day to } 1^{\text {s }} \\
\text { Germination }\end{array}$ & \% Germination & $\begin{array}{l}\text { Shoot Height } \\
(\mathrm{cm})\end{array}$ & Total Biomass $(\mathrm{g})$ & Root/Shoot Ratio \\
\hline Effect & F-value & F-value & F-value & F-value & F-value \\
\hline water & 1.24 & 0.02 & 5.04 & 2.68 & 4.22 \\
\hline soil & 3.03 & $4.42^{*}$ & $26.06^{* * *}$ & $31.53 * * *$ & $3.24(\mathrm{P}=0.051)$ \\
\hline soil*water & 0.75 & 1.26 & 1.04 & 1.89 & 0.61 \\
\hline spp & $75.53^{* * *}$ & $25.94^{* * *}$ & $97.78^{* * *}$ & $6.78^{* * *}$ & $56.62 * * *$ \\
\hline spp*water & 1.09 & 1.14 & 0.72 & 0.84 & 2.14 \\
\hline spp*soil & $2.34^{*}$ & 1.86 & $5.58^{* * *}$ & $3.57 *$ & $3.82^{* * *}$ \\
\hline spp*soil*water & 1.05 & 0.73 & 0.72 & 0.59 & 1.27 \\
\hline
\end{tabular}

seedlings from being damaged by extreme heat on hot summer days. The mean temperature for the greenhouse during the experiment was $29.4 \mathrm{C}$, with a high and low of $40 \mathrm{C}$ and $26.1 \mathrm{C}$, respectively, from Jun. to Oct. 2005, when the experiment was terminated.

The water treatments differed in the number of watering days per week (High $=6 \mathrm{~d}$, Intermediate $=4 \mathrm{~d}$, Low $=2 \mathrm{~d}$ ) and total water per week. The average amount of water that a pot received per watering day was $115 \mathrm{ml}$. Thus, the total water applied per pot per week was $690 \mathrm{ml}, 460 \mathrm{ml}$ and $230 \mathrm{ml}$ for high, intermediate and low water treatments, respectively.

We recorded the day of first seed germinating in each pot and total germination after thirty-five days. At that time, we thinned seedlings to one per pot, retaining the largest and the closest to the center in each pot. In early Oct., when some plants appeared ready to abscise leaves, we recorded shoot height and harvested the shoots and roots separately, using soil sieves to minimize the loss of fine roots. Plant parts were dried in an oven $(70 \mathrm{C})$ for 1 wk and then weighed.

Statistical analysis. - We used mixed-model analyses of variance (PROC MIXED, SAS, 2003) to determine the effects of species, soil type and water regime on the dependent variables: days to first germination, final \% germination, shoot height, total biomass and root/shoot ratio. Percent germination and total biomass were arcsine and log-transformed, respectively, before analysis. Block was treated as a random factor, and Type III Sums of Squares were used to determine significance. We performed multiple pairwise comparisons, using Least Squares Means (LSMEANS) and Tukey's adjustment, to determine where significant differences existed between species and soil types.

\section{Results}

Germination.-Species differed significantly in germination time (Table 2). The first seedlings of Liquidambar and Platanus appeared significantly earlier than did seedlings of Ailanthus and Paulownia by approximately $7 \mathrm{~d}$ (Fig. 1a). Also, species differed in their response to soil type, as measured in day of first appearance. Paulownia germinated later than did the other species in the disturbed soils but not in forested soils (e.g., for PDs: Ailanthus vs. Paulownia $\mathrm{P}=<0.0001$; Liquidambar vs. Paulownia $\mathrm{P}=0.0007$; Platanus vs. Paulownia $\mathrm{P}=<0.0001)$. Species-specific differences in timing were most apparent in the piedmont disturbed soil containing organic matter $\left(\mathrm{PD}_{\mathrm{U}}\right)$ soil: Ailanthus vs. Platanus $\mathrm{P}=$ 0.0434 ; Ailanthus vs. Paulownia $\mathrm{P}=0.0274$; Liquidambar vs. Paulownia $\mathrm{P}=0.0042$; Platanus vs.

Paulownia $\mathrm{P}=<0.0001)$. 

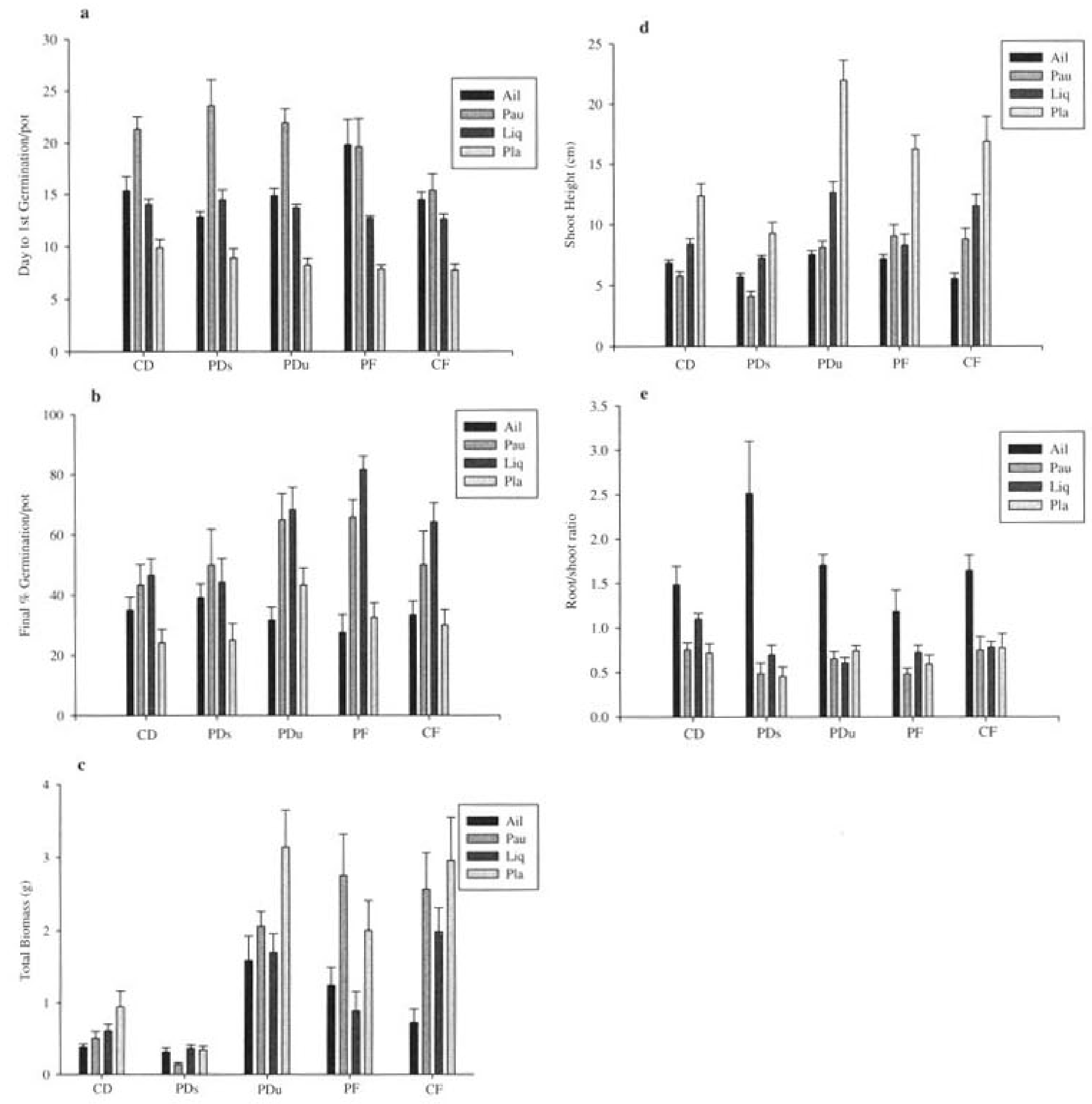

FIG. 1.-Mean values ( $\pm 1 \mathrm{SE}$ ) shown by species and soil type for: $\mathbf{a}$. Day to first germination per pot, $\mathbf{b}$. Final \% germination per pot, c. Total Biomass, d. Shoot Height, e. Root/Shoot Ratio. Soils: CD (Coastal Plain disturbed), $\mathrm{PD}_{\mathrm{S}}$ (Piedmont disturbed no organic matter), $\mathrm{PD}_{\mathrm{U}}$ (Piedmont disturbed + organic matter), PF (Piedmont forested), CF (Coastal Plain forested). Exotic species: Ail (Ailanthus altissima), Pau (Paulownia tomentosa). Native species: Liq (Liquidambar styraciflua), Pla (Platanus occidentalis)

By the end of $5 \mathrm{wk}, 90 \%$ of recorded germination had occurred in all species, and species significantly differed in final \% germination (Table 2). Paulownia and Liquidambar exhibited higher germination $(>50 \%)$ than did Ailanthus and Platanus $(30-40 \%)$ averaged over soil types (Fig. 1b). Also, soil significantly influenced total germination averaged over species (Table 2). Percent germination was higher on the piedmont organic soils (mean \% germination: $\mathrm{CD}=39.5, \mathrm{PD}_{\mathrm{S}}=44.8, \mathrm{PD}_{\mathrm{U}}=61.4, \mathrm{PF}=61.2, \mathrm{CF}=51.2$ ). Only in these soils did we observe species-specific differences in \% germination. Paulownia and /or Liquidambar showed higher germination than did the other species (pairwise comparisons for $\mathrm{PD}_{\mathrm{U}}$ soil: $\mathrm{P}$ $=0.0318$ for Ailanthus vs. Liquidambar, $\mathrm{P}=0.0410$ for Ailanthus vs. Paulownia ; for $\mathrm{PF}$ soil: $\mathrm{P}=$ 
$<0.0001$ for Ailanthus vs. Liquidambar; $\mathrm{P}=0.0004$ for Liquidambar vs. Platanus). In contrast to soil, water treatment did not affect \% germination (Table 2).

Seedling growth.-Species and soil type, but not water, contributed significantly to the observed variation in total biomass, shoot height and root/shoot ratio (Table 2). Across all soil types, Platanus and Paulownia had greater total biomass compared to Ailanthus and Liquidambar (Fig. 1c). Platanus produced the most while Ailanthus produced the least. Total biomass was greatest on organic soils $\left(\mathrm{CF}, \mathrm{PD}_{\mathrm{U}}\right.$ and $\mathrm{PF}$ soils), and it was in these soils that species showed significant pairwise differences in biomass (for PF soil: Liquidambar vs. Paulownia $\mathrm{P}=0.0190$; for $\mathrm{PD}_{\mathrm{U}}$ soil: Ailanthus vs. Platanus $\mathrm{P}=0.0405$; for $\mathrm{CF}$ soil: Ailanthus vs. Platanus $\mathrm{P}=0.0009$; Ailanthus vs. Paulownia $\mathrm{P}=0.0440)$.

Shoot height significantly differed among species and soils (Table 2). Seedlings were shorter and showed only one species-specific difference in the non-organic soils (for CD soil: Platanus vs. Paulownia $\mathrm{P}=0.0004$ ) (Fig. 1d). In the organic soils, species on average grew taller, and they differed in height. Liquidambar and especially Platanus grew taller than did Ailanthus and Paulownia (Fig. 1d). $\mathrm{PD}_{\mathrm{U}}$ and CF soils showed the greatest number of speciesspecific differences (for $\mathrm{PD}_{\mathrm{U}}$ soil: Ailanthus vs. Liquidambar $\mathrm{P}=0.0089$; Ailanthus vs. Platanus $\mathrm{P}=<0.0001$; Liquidambar vs. Platanus $<0.0001$; Platanus vs. Paulownia $\mathrm{P}=<0.0001$; for CF soil: Ailanthus vs. Liquidambar $\mathrm{P}=0.0010$; Ailanthus vs. Platanus $\mathrm{P}=<0.0001$; Liquidambar vs. Platanus $\mathrm{P}=0.0113$; Platanus vs. Paulownia $\mathrm{P}=<0.0001)$.

Biomass partitioning significantly differed among species and soils (Table 2). Ailanthus, which produced short shoots and the least total biomass, also produced only one-third to one-half the shoot biomass as did the other species (Mean Shoot Biomass for Ailanthus $=$ $0.310 \pm 0.042 ;$ Liquidambar $=0.666 \pm 0.080 ;$ Platanus $=1.05 \pm 0.118 ;$ Paulownia $=0.958$ \pm 0.128 ). Its root biomass was also relatively low (Mean Root Biomass for Ailanthus $=$ $0.535 \pm 0.073 ;$ Liquidambar $=0.467 \pm 0.052 ;$ Platanus $=0.897 \pm 0.122 ;$ Paulownia $=0.665$ $\pm 0.0918)$. However, because the root biomass was more similar to that of other species than was shoot biomass, Ailanthus showed the highest and most variable root/shoot ratio across soil types (Fig. 1e). Root/shoot ratios among the other species were not significantly different. Thus, the significant species by soil interaction was explained by Ailanthus (Table 2).

\section{Discussion}

From the standpoint of germination and early seedling growth, our study suggests that broadcasting seeds of native tree species, such as Platanus and Liquidambar, onto bare disturbed sites may help slow the establishment of exotic species, such as Ailanthus and Paulownia. Both Platanus and Liquidambar germinated more quickly that did Ailanthus and Paulownia. Liquidambar's germination percentage was among the highest for all species, and its germination was rapid over all soil types. Platanus had moderate germination; however, it germinated most quickly. Platanus seedlings appeared about 5-10 d earlier, on average, than Ailanthus or Paulownia. In a land restoration context, differences in germination are likely to be important. For example, as illustrated by our data, Ailanthus puts most of its resources into root growth in the first year (also see Pan and Bassuk, 1986). Once established, its rapid clonal growth and high reproductive output make the species difficult to eradicate (Adamik and Brauns, 1957; Cozzo, 1972; Hu, 1979; Hoshovsky, 1988; Kowarik, 1995; Knapp and Canham, 2000). Numerous studies have shown that earlier germination gives seedlings more time to capture space and resources needed for growth (e.g., Streng et al., 1989; Jones et al., 1997). Also, when natural precipitation events that promote germination are short-lived (not the case in our experiment) rapid germination may be 
critical for successful germination. Earlier germination also enhances a seedling's subsequent competitive ability (e.g., Jones and Sharitz, 1989; Jones et al., 1989). For example, increased height is advantageous when subsequent competition for light intensifies. The natives Platanus and Liquidambar produced significantly taller shoots than did Paulownia and Ailanthus.

Established seedlings of native tree species, including Platanus, have been successfully used in the restoration of surface mine operations throughout the eastern US (Zeleznik and Skousen, 1996). Liquidambar tree seedlings have been used for transplanting into deforested areas in Mexican cloud forests (Pedraza and Williams-Linera, 2003; Pedraza-Perez and Williams-Linera, 2005). Our study suggests that seeds, in addition to seedlings, might be effectively used for land restoration. We have found only one study that evaluates the effects of sowing seeds of native onto bare land. Simmons (2005) observed that oversowing seeds of a native herbaceous species Indian blanket (Gaillardia pulchella Foug.) reduced the aboveground productivity of the invasive annual bastard cabbage (Rapistrum rugosum (L.) All.)) by $72 \%$ and reduced seed set by $83 \%$. Such experiments using native tree species would be worthwhile.

Although our experiment is limited by the fact that it was conducted in a greenhouse, the results do suggest that Liquidambar and Platanus could potentially be good candidates for use in management programs designed to slow the spread of invasive tree species and to facilitate the restoration of native plant communities. The results also suggest that additional studies comparing the competitive abilities of natives and exotics would be valuable. Preventing the invasion of an exotic is usually more cost-effective than eradication or containment after an invasive has established locally (Mack et al., 2000; Rejmanek, 2000; Leung et al., 2002).

Acknowledgments. - We thank Bill Adams for the City of Greensboro and Dr. Clyde Bogle from the Upper Coastal Plain Research Station for their assistance with soil collection sites, Scott J. Richter for statistical help, P.Dan Royall, Paul Mou and Bruce Kirchoff for helpful suggestions, Robert M. Northington for logistic help, and UNCG Biology Department for financial support.

\section{LITERATure Cited}

Adamik, K. J. And F. E. Brauns. 1957. Ailanthus altissima (tree of heaven) as a pulpwood Part II. Tappi, 40:522-527.

BONNER, F. T. 1974a. Liquidambar styraciflua L., p. 505-507. In: C. S. Schopmeyer (ed.). Seeds of woody plants in the US. USDA Agriculture Handbook 450, Washington, DC.

1974b. Platanus L., p. 641-644. In: C. S. Schopmeyer (ed.). Seeds of woody plants in the US. USDA Agriculture Handbook 450, Washington, DC.

And J. D. Burton. 1974. Paulownia tomentosa (Thumb.) Sieb \& Zucc Royal Paulownia, p. 572-573. In: C. S. Schopmeyer (ed.). Seeds of woody plants in the US. USDA Agriculture Handbook 450, Washington, DC.

BuCkL.EY, Y. M., M. REes, Q. PANTER ANd M. LONSDAlE. 2004. Modelling integrated weed management of an invasive shrub in tropical Australia. J. Appl. Ecol., 41:547-560.

Butterfiel.d, B. J., W. E. Rogers and E. Siemans. 2004. Growth of Chinese tallow tree (Sapium sebiferum) and four native trees under varying water regimes. Texas J. Sci., 56:335-346.

Bizrs, J. E., S. Reichard, J. M. Randall, I. M. Parker, C. S. Smith, W. M. Lonsdale, A. E. Atkinson, T. R. Seastedt, M. Williamson, E. Chornesky and D. Hayes. 2002. Directing research to reduce the impacts of nonindigenous species. Cons. Biol., 16:630-640.

Cozzo, D. 1972. Initial behavior of Ailanthus altissima in experimental plantation. Revista Forestal Argentina, 16:47-52. (In Spanish) 
Hoshovsky, M. C. 1988. Element stewardship abstract for Ailanthus altissima. The Nature Conservancy, USA.

Hu, S. Y. 1979. Ailanthus. Amoldia, 39:29-50.

JoNes, R. H. AND R. R. SHARITz. 1989. Potential advantages and disadvantages of germinating early for trees in floodplain forests. Oecologia, 81:443-449.

AND K. W. MCLEOD. 1989. Effects of flooding and root competition on growth of shaded bottomland hardwood seedlings. Am. Midl. Nat., 121:165-175.

B. P. AIIIEN AND R. R. Sharrtz. 1997. Why do early-emerging tree seedlings have survival advantages?: A test using Acer rubrum (Aceraceae). Am. J. Bot., 84:1714-1718.

KNapp, L. B. AND C. D. CaNham. 2000. Invasion of an old growth forest in New York by Ailanthus altissima: sapling recruitment in canopy gaps. J. Torrey Bot. Soc., 127:307-315.

Kowarik, I. 1995. Clonal growth in Ailanthus altissima on a natural site in West Virginia. J. Veg. Sci., 6:853-856.

Leung, B., D. M. Lodge, D. Finoff, J. F. Shogren, M. A. Lewis and G. Lamberti. 2002. An ounce of prevention or a pound of cure: Bioeconomic risk analysis of invasive species. Proc, R. Soc. Lon. Ser. B., 269:2407-2413.

Lrтtı.., S. 1974. Ailanthus altissima (Mill.) Swingle Ailanthus, p. 212-202. In: C. S. Schopmeyer (ed.). Seeds of woody plants in the US. USDA Agriculture Handbook 450, Washington, DC.

MacK, R. M., D. Simberloff, W. M. Lonsdale, H. Evans, M. Clout and F. A. Bazzaz. 2000. Biotic Invasions: Causes, epidemiology, global consequences, and control. Issues in Ecol., 10:689-710.

Mandryk, A. M. AND R. W. Wein. 2006. Exotic vascular plant invasiveness and forest invasibility in urban boreal forest types. Bio. Invas., 8:1651-1662.

Mғнц.ıн, A. 1953. Determination of P, K, Mg, and $\mathrm{NH}_{4}$. Div. Mimeo N.C. Dept of Agri. Raleigh. www. ncagr.com/agronomi/pdffiles/mehlich53.pdf.

MuL...R, J. H. 1998. Exotic invasive plants in southeastern forests, p. 97-105. In: K. O. Britton (ed.). Proc. of the Exotic Pests of Eastern Forests.

Newsome, A. E. AND I. R. Nobl.E. 1986. Ecological and physiological characters of invading species, p. 1-20. In: R. H. Groves and J. J. Burdon (eds.). Ecology of biological invasions: An Australian Perspective. Cambridge Univ. Press, New York.

National. Resources Conservation Service (NRCS). 2008. Soil Extent Mapping (SEM) Tool. http://www. cei.psu.edu/soiltool.

Owen, W. 2002. The history of native plant communities in the south, p. 47-62. In: D. W. Wear and J. G. Greis (eds.). The southern forest resource assessment: Tech. Report, U.S. Forest Service Gen. Tech. Report, SRS-53.

PAN, E. AND N. L. Bassuk. 1986. Establishment and distribution of Ailanthus altissima in the urban environment. J. Envi. Hort., 4:1-4.

PedruzA, R. A. And G. Williams-Liners. 2003. Evaluation of native tree species for the rehabilitation of deforested areas in a Mexican cloud forest. New Forests, 26:83-99.

Pedraza-Perez, R. A. and G. Williams-Linera. 2005. Microhabitat conditions for germination and establishment of two tree species in the Mexican montane cloud forest. Agrociencia, 39:457-467.

REJMANEK, M. 2000. Invasive plants: approaches and predictions. Austral. Ecol., 25:497-506.

SAS User's Manual. 2003, SAS Institute, Cayy, North Carolina.

Sımmons, M. T. 2005. Bullying the bullies: The selective control of an exotic, invasive annual (Rapistrum rugosum) by oversowing with a competitive native species (Gaillardia pulchella). Restor. Ecol., 13:609-615.

Streng, D. R., J. S. Glitzenstein and P. A. Harcombe. 1989. Woody seedling dynamics in an east Texas floodplain forest. Ecol. Monogr., 59:177-204.

ZEI.EZNIK, J. D. AND J. G. Skousen. 1996. Survival of three tree species on old reclaimed surfacemines in Ohio. J. Envi. Qual., 25:1429-1435. 